\title{
"Physician Burnout" The Problem is known, but What about the solution? Can Effective Practice Management and Education Reduce the Physical and Psychological Stress of the Operating Room?
}

\author{
Chernov M*, Vick A, Ramachandran S, Reddy S, Leyvi G and Delphin E \\ Montefiore Medical Center, United States
}

Submission: April 12, 2019; Published: April 26, 2019

*Corresponding author: Mikhail Chernov, Assistant Professor, Montefiore Medical Center, 1825 Eastchester road, Bronx, New York, United States

\begin{abstract}
Background: Extensive data shows the direct correlation between overall job satisfaction and state of burnout and depression (BO/DP) among healthcare professionals. However, the importance of competent, science-based practice management combined with cross-departmental education as a tool to improve staff satisfaction and alleviate burnout is still unknown.
\end{abstract}

Material and Method: We conducted an internal single campus study involving attendings and residents from departments of surgery and anesthesiology on effect of practice management efficiency, teamwork and an interdepartmental educational approach on state of BO/DP based on response to a validated questionnaire.

Results: Overall 95 physicians were surveyed. Majority of attendings surgeons and anesthesiologists experienced symptoms of BO/DP (80.9\% and $66.6 \%$ respectively). Most of them appreciate the correlation between symptoms of BO/DP and efficiency of operating room (OR) management, level of interpersonal communication and cooperation as well as importance of a teamwork and education as an effective tool to alleviate this condition. Residents from both departments consider the state of burnout much less prevalent. Their understanding of OR management, interpersonal communication, cooperation and teamwork was much less determined as well. However, anesthesia residents showed better understanding of the importance of inter-departmental education compare to their surgical colleagues.

Conclusion: The effectiveness of OR management directly correlates with the symptoms of BO/DP. Interdepartmental education on teamwork, communication and cooperation helps to improve efficiency of OR management and subsequently to minimize negative effect of burnout and depression.

Keywords: Depression; Burnout; Anesthesia; Depersonalization; Critical care

\section{Introduction}

The issue of burnout and feeling depressed among physicians is far from a new phenomenon [1-3]. Recent technological "breakthroughs" give physicians the ability to perform better and to "produce" more in a shorter period of time [4] but at the same time it forces the educational process to focus predominantly on simple interpretation and application of data rather than on clinical and humane aspects of medicine, thus "depersonalizing" the entire process. This "depersonalization" combined with the specifics of our profession including the continuous multilevel physical and psychological pressures create a perfect breeding ground for BO/DP symptoms. According to research published in the Archives of Internal Medicine in 2012 on work-life balance, almost $50 \%$ of physicians responding to a survey reported at least one symptom of burnout, a number that is significantly higher compared to the general working US population [5].
The 2018 National Physician Burnout and Depression report revealed that among multiple medical specialties, internists, family medicine and emergency/critical care physicians are the most susceptible to this condition [6]. According to the Anesthesiology Lifestyle Report on Bias and Burnout in 2016, 50\% of anesthesiologists reported symptoms of burnout or depression, thus positioning our specialty somewhere in the middle of all surveyed medical professions [7]. Interestingly enough, if in 2016 most anesthesiologists chose "too many bureaucratic tasks" as the main cause of BO/DP, [8] the same report in 2018 listed "lack of respect from administrators/employers or staff" as the most common cause, followed by "spending too many hours at work," and "feeling like just a cog in the wheel" [9]. On our opinion, this change may indicate the ongoing systematic failure created by and directly related to a "monetization" and "depersonalization" of the healthcare industry in general which negatively impacts not only 
"physician-to-physician" but "physician-to- patient" professional interaction.

Considering the relatively isolated, highly stressful, fast-paced environment of the operating room, it is somewhat surprising that the burnout among the members of our field is not even higher. Perhaps it is a result of self-selection among physicians who choose to serve in an arena of anesthesiology and critical care that they are mentally ready to and capable of managing the associated steady state of stress. However, inefficient OR management, lack of interpersonal professional communication and cooperation among the members of the team may become another source of unnecessary tension and confrontation adding tremendously to already high level of stress. Multiple attempts to improve quality of OR management and teamwork were made in the past through application of a random Practice Improvement Methodologies (PIMs) and team-building exercises but yielded minimal (if any) influence on overall efficiency and quality of care [10] and their effect on physician's wellbeing have never been evaluated.

In 2012 Department of Anesthesiology at Montefiore Medical Center developed and initiated two separate programs specifically designed to improve quality and efficiency of OR management - Integrated Practice Improvement Solutions (IPIS) [11] and teamwork via cross-departmental non - simulation based education for surgical residents (4 Steps-To-Team) [12]. These projects were carried out in a single campus (out of five available) of the medical center. It has been reported that the implementation of IPIS helps to significantly improve OR efficiency and productivity without substantive changes in staffing or rooms allocation [11]. Integration of the principles of "4 StepsTo-Team" into residency educational program at early stages

Table 2: Nine points questionnaire.

\begin{tabular}{|c|c|c|c|c|c|c|c|}
\hline \multirow[b]{2}{*}{ 1. What is your Department } & \multirow{2}{*}{$\begin{array}{l}\text { Anesthesiology } \\
\text { Attending/ } \\
\text { Resident }\end{array}$} & \multirow{2}{*}{$\begin{array}{c}\text { Surgery } \\
\text { Attending/ } \\
\text { Resident }\end{array}$} & & & & & \\
\hline & & & & & & & \\
\hline 2. Which campus is your primary site of practice? & Moses & Weiler & Wakefield & Hutch & WSQ & & \\
\hline 3. Do you work at more than 1 of the above locations? & YES & NO & & & & & \\
\hline $\begin{array}{l}\text { For Q4-8, use the scale to the right to indicate your } \\
\text { degree of agreement with the statement with the } \\
\text { larger number indicating strong agreement }\end{array}$ & $\begin{array}{l}\text { Strongly } \\
\text { Disagree }\end{array}$ & $\begin{array}{l}\text { Moderately } \\
\text { Disagree }\end{array}$ & $\begin{array}{l}\text { Mildly } \\
\text { Disagree }\end{array}$ & Neutral & $\begin{array}{l}\text { Mildly } \\
\text { Agree }\end{array}$ & $\begin{array}{l}\text { Moderately } \\
\text { Agree }\end{array}$ & $\begin{array}{l}\text { Strongly } \\
\text { Agree }\end{array}$ \\
\hline $\begin{array}{l}\text { 4. I have experienced feelings of burnout and/or } \\
\text { depression }\end{array}$ & 1 & 2 & 3 & 4 & 5 & 6 & 7 \\
\hline $\begin{array}{l}5 . \text { The way the operating room is managed impacts } \\
\text { the degree of burnout and/or depression that I feel }\end{array}$ & 1 & 2 & 3 & 4 & 5 & 6 & 7 \\
\hline $\begin{array}{l}\text { 6. A lack of interpersonal communication and } \\
\text { cooperative behavior between OR team members } \\
\text { has contributed to my feelings of burnout and/or } \\
\text { depression }\end{array}$ & 1 & 2 & 3 & 4 & 5 & 6 & 7 \\
\hline $\begin{array}{c}\text { 7. I believe that improving teamwork in the OR can } \\
\text { reduce stressors that contribute to feelings of being } \\
\text { burnout and/or depressed }\end{array}$ & 1 & 2 & 3 & 4 & 5 & 6 & 7 \\
\hline $\begin{array}{l}\text { 8. Cross-departmental education in OR management } \\
\text { including teamwork and communication would be } \\
\text { likely to improve quality of care and reduce anxiety } \\
\text { found in the workplace }\end{array}$ & 1 & 2 & 3 & 4 & 5 & 6 & 7 \\
\hline
\end{tabular}

of training helped residents of both specialties to improve their interpersonal and communication skills, professional behavior and confidence [12]. However, the influence of these changes on overall staff satisfaction has never been evaluated. The aim of this study is to assess the effect of science-based OR management and inter-departmental education as a tool for improvement of OR staff satisfaction in attempt to minimize the symptoms of BO/DP.

\section{Materials and Methods}

Table 1: IPIS influence on Operating Room efficiency.

\begin{tabular}{|c|c|c|c|c|c|}
\hline Year & $\mathbf{2 0 1 0}$ & $\mathbf{2 0 1 1}$ & $\mathbf{2 0 1 2}$ & $\mathbf{2 0 1 3}$ & $\mathbf{2 0 1 4}$ \\
\hline Total Case Load & 9744 & 9571 & 9236 & 10226 & 10152 \\
\hline Case load \% change & & -1.78 & -3.5 & 10.72 & -0.72 \\
\hline $\begin{array}{c}\text { Anesth. Revenue \% } \\
\text { change }\end{array}$ & & -1.88 & -2.1 & 6.96 & 4.45 \\
\hline OR Revenue \% change & & & 12.05 & 18.56 & 10.26 \\
\hline OR Utilization & 54 & 52.5 & 52.9 & 55.6 & 51.2 \\
\hline
\end{tabular}

Our unique managerial system - Integrated Practice Improvement Solutions (IPIS) was developed in 2011 and fully implemented in 2012 and within the following 3 years helped to significantly improve OR efficiency and productivity (Table 1). Cross-departmental non-simulation based educational program for surgical residents was developed and implemented in 2013 as a part of "4 Steps-to-Team" - an innovative approach to a teambuilding process in the operating room. Even though previously reported results were preliminary, they clearly showed a positive trend in inter-personal communication between junior members of both departments, better understanding of the concept of leadership, cooperation and teamwork in the OR [15]. Both programs were implemented at a single (out of five available) location within our academic medical center. 


\begin{abstract}
9. Please answer this question, if you have answered "YES" for question 3. In your opinion, which campus best reflects your view on teamwork, cooperation and coordination among team members?
\end{abstract}

Total 95 physicians - attending surgeons $(n=24)$, attending anesthesiologists $(n=30)$, resident surgeons $(n=17)$ and resident anesthesiologists $(n=24)$ participated in the survey conducted in a single campus at Montefiore Medical Center. However, all participants were practicing in at least two or more locations. The number and type of responders were determined by staff availability at current location and structure of the institution. The nine points questionnaires (Table 2) was developed and validated by the senior members of the Department of Anesthesiology. Questions were focusing on understanding of the value of teamwork, communication and cross-training in general and its significance as a tool to minimize symptoms of BO/DP in particular. The questionnaire was distributed and collected anonymously. We compared the number of positive responses characterizing B0/DP (as answer "Yes" to Mildly agree, Moderately agree and Strongly agree as Total agree number) between Attendings and Residents within subspecialty as well as All Attendings (Anesthesia and Surgery) to All residents (Anesthesia and Surgery) by Pearson Chi-Square or Fisher's exact test as appropriate. Spearman correlation test was used to explore correlation between symptoms of BO/DP and efficiency of OR management, level of interpersonal communication and cooperation. To test the influence of the practice site on BO/DP we did logistic regression for All Attendings vs. All Residents and their primary campus site. We considered $p$ value $<0.05$ as statistically significant.

Results

Table 3: Comparison in responses of Surgical Attendings to Anesthesia Attendings and Surgical Residents to Anesthesia Residents.

\begin{tabular}{|c|c|c|c|c|c|c|c|c|c|c|c|c|c|c|c|}
\hline \multirow{2}{*}{$\begin{array}{l}\text { Questions } \\
\text { Particip ants } \\
\end{array}$} & \multicolumn{3}{|c|}{$\begin{array}{l}\text { Q4. I have experience } \\
\text { feeing of BO/DP }\end{array}$} & \multicolumn{3}{|c|}{$\begin{array}{l}\text { Q } 5 . \text { The way the operating } \\
\text { room is managed impacts } \\
\text { the degree of BO/DP that } \\
\text { I feel }\end{array}$} & \multicolumn{3}{|c|}{$\begin{array}{c}\text { Q 6. A lack of } \\
\text { interpersonal } \\
\text { communication and } \\
\text { cooperative behavior } \\
\text { between OR team } \\
\text { members have } \\
\text { contributed to my feeling } \\
\text { of BO/DP }\end{array}$} & \multicolumn{3}{|c|}{$\begin{array}{l}\text { Q 7. I believe that } \\
\text { improving teamwork } \\
\text { in the OR can reduce } \\
\text { stressors that contribute } \\
\text { to feeling of being BO/DP }\end{array}$} & \multicolumn{3}{|c|}{$\begin{array}{l}\text { Q 8. Cross-departmental } \\
\text { education in or } \\
\text { management including } \\
\text { teamwork and } \\
\text { communication would be } \\
\text { likely to improve quality } \\
\text { of care and reduce anxiety } \\
\text { found in the work place }\end{array}$} \\
\hline & Disagree & Neutral & Agree & Disagree & Neutral & Agree & Disagree & Neutral & Agree & Disagree & Neutral & Agree & Disagree & Neutral & Agree \\
\hline $\begin{array}{c}\text { Surgical } \\
\text { Attendings }\end{array}$ & 2 (8.3) & $2(8.3)$ & $20(83.3$ & $1(4.2)$ & $1(4.2)$ & $\begin{array}{c}22 \\
(91.6)\end{array}$ & $2(0.83)$ & $4(16.6)$ & $\begin{array}{c}18 \\
(75.0)\end{array}$ & $0(0)$ & $1(4.2)$ & $\begin{array}{c}23 \\
(95.8)\end{array}$ & $1(4.2)$ & $1(4.2)$ & $\begin{array}{c}22 \\
(91.7)\end{array}$ \\
\hline $\begin{array}{l}\text { Anesthesia } \\
\text { Attendings }\end{array}$ & 7 (2.3) & $\begin{array}{c}3 \\
(10.0)\end{array}$ & $\begin{array}{c}20 \\
(66.7)\end{array}$ & $3(10.0)$ & $3(10.0)$ & $\begin{array}{c}24 \\
(80.0)\end{array}$ & $4(13.3)$ & $4(13.3)$ & $\begin{array}{c}22 \\
(73.3)\end{array}$ & $2(6.6)$ & $\begin{array}{c}3 \\
(10.0)\end{array}$ & $\begin{array}{c}25 \\
(83.3)\end{array}$ & $1(3.3)$ & 4 (13.3) & $\begin{array}{c}25 \\
(83.3)\end{array}$ \\
\hline $\mathrm{P}_{\text {value }}{ }^{1}$ & 0.34 & 0.83 & 0.16 & 0.42 & 0.41 & 0.23 & 0.56 & 0.73 & 0.89 & NA & 0.41 & 0.15 & 0.87 & 0.25 & 0.37 \\
\hline $\begin{array}{l}\text { Surgical } \\
\text { Residents }\end{array}$ & $6(35.3)$ & $\begin{array}{c}4 \\
(23.5)\end{array}$ & 7 (41.2) & $4(23.5)$ & 8 (47.1) & $\begin{array}{c}5 \\
(29.4)\end{array}$ & $2(11.7)$ & 5 (29.4) & $\begin{array}{c}10 \\
(58.8)\end{array}$ & $0(0)$ & $1(5.9)$ & $\begin{array}{c}16 \\
(94.1)\end{array}$ & 2 (11.7) & 3 (17.6) & $\begin{array}{c}12 \\
(70.6)\end{array}$ \\
\hline $\begin{array}{l}\text { Anesthesia } \\
\text { Residents }\end{array}$ & $9(37.5)$ & $\begin{array}{c}7 \\
(29.2)\end{array}$ & 8 (33.3) & 4 (16.7) & 5 (20.1) & $\begin{array}{c}15 \\
(62.5)\end{array}$ & 3 (12.5) & $5(20.8)$ & $\begin{array}{c}16 \\
(66.7)\end{array}$ & $2(2.1)$ & $0(0)$ & $\begin{array}{c}24 \\
(100)\end{array}$ & $0(0)$ & $2(8.3)$ & $\begin{array}{c}22 \\
(91.6)\end{array}$ \\
\hline $\mathrm{P}_{\text {value }}{ }^{2}$ & 0.89 & 0.69 & 0.61 & 0.58 & 0.08 & 0.004 & 0.58 & 0.53 & 0.61 & NA & 0.23 & 0.23 & 0.08 & 0.37 & 0.5 \\
\hline
\end{tabular}

$P$ value ${ }^{1}$ address difference between Surgical Attendings and Anesthesia Attendings.

$P$ value ${ }^{2}$ address difference between Surgical Residents and Anesthesia Residents.

According to the survey, the vast majority of surgical (95.9\%) and anesthesiology attendings (77\%) were practicing at two or more locations. $100 \%$ of residents from both departments were practicing at two locations both of which are involved in the educational process by the structure of the institution. The majority of Surgical Attendings (20 out of 24,83\%) and Anesthesiology Attendings (20 out of 30,66\%, p = 0.16) reported symptoms of BO/DP (by responding "Yes" to Question 4 which states "I have experienced feelings of burnout and/or depression" as Mildly agree, Moderately agree or Strongly agree) (Table 3). Most of them appreciate the correlation between symptoms of BO/DP and efficiency of OR management ( $r=0.6, p<0.001)$, level of interpersonal communication and cooperation $(r=0.41$, $\mathrm{p}<0.001$ ). These symptoms were less prevalent among surgical
7 (41\%) and anesthesia residents and 8 (33.3\%), p = 0.61 respectively (Table 4).

Residents from both departments consider the state of burnout much less significant compare to attendings (residents $36.69 \%$ vs. attendings $66.92 \%, p=0.002$ ) (Table 4). Their understanding of OR management, interpersonal communication, cooperation and teamwork was much less determined as well (residents $51.22 \%$ vs. attendings $83.2 \%, \mathrm{p}=0.001$ ). However, anesthesia residents showed better understanding of the "The way the operating room is managed impacts the degree of BO/ DP that I feel" compare to their surgical colleagues (anesthesia residents $62.5 \%$ vs surgical residents $29.4 \%, p=0.04$ ) (Table 3 ).

The importance of interpersonal communication and 
cooperation as a useful tool to alleviate the symptoms of BO/ DP was comparable across the specialties independently from the level of training (Attending vs. resident) (Q6: "A lack of interpersonal communication and cooperative behavior between OR team members has contributed to my feelings of burnout and/ or depression") (Table $3 \& 4$ ). The value of teamwork itself as well as Cross-Departmental education in OR management, teamwork and leadership in reduction of stressors leading to BO/DP were also comparable for each group of participants (Q7: I believe that improving teamwork in the OR can reduce stressors that contribute to feeling of being burned out and/or depressed) (Table 4). As we stated previously, the IPIS as an OR management approach and "4 Steps-to-Team" educational methodology was carried out at a single (out of 5 available) location (Location 2) within our academic medical center. Locations 1,2 and 3 are a multispecialty inpatient/outpatient facility performing mixed of inpatient and ambulatory cases. Locations 4 and 5 are an ambulatory surgery facility performing $100 \%$ outpatient procedures. Out of all participants practicing at those locations, fifty-five (57.8\%) chose (Location 2) as the site that best reflects their views on teamwork, cooperation and coordination as compared to $21 \%$ for Location 1, 15\% for Location 4 and $4.3 \%$ and $1.0 \%$ for Location 3 and 5 respectively.

Table 4: Comparison in responses of all attendings to all residents to questions 4 - 8 .

\begin{tabular}{|c|c|c|c|c|c|c|c|c|c|c|c|c|c|c|c|}
\hline \multirow{2}{*}{$\begin{array}{l}\text { Questions } \\
\text { Partici- } \\
\text { pants }\end{array}$} & \multicolumn{3}{|c|}{$\begin{array}{l}\text { Q4. I have experience feeing } \\
\text { of BO/DP }\end{array}$} & \multicolumn{3}{|c|}{$\begin{array}{l}\text { Q 5. The way the operating } \\
\text { room is managed impacts } \\
\text { the degree of BO/DP that } \\
\text { I feel }\end{array}$} & \multicolumn{3}{|c|}{$\begin{array}{l}\text { Q 6. A lack of interpersonal } \\
\text { communication and } \\
\text { cooperative behavior } \\
\text { between OR team members } \\
\text { have contributed to my } \\
\text { feeling of BO/DP }\end{array}$} & \multicolumn{3}{|c|}{$\begin{array}{l}\text { Q } 7 . \text { I believe that } \\
\text { improving teamwork in the } \\
\text { OR can reduce stressors } \\
\text { that contribute to feeling of } \\
\text { being BO/DP }\end{array}$} & \multicolumn{3}{|c|}{$\begin{array}{l}\text { Q 8. Cross-departmental } \\
\text { education in OR } \\
\text { management including } \\
\text { team work and } \\
\text { communication would be } \\
\text { likely to improve quality } \\
\text { of care and reduce anxiety } \\
\text { found in the workplace }\end{array}$} \\
\hline & Disagree & Neutral & Agree & Disagree & Neutral & Agree & Disagree & Neutral & Agree & Disagree & Neutral & Agree & Disagree & Neutral & Agree \\
\hline $\begin{array}{c}\text { Attending, } \\
\text { number } \\
(\%)\end{array}$ & $\begin{array}{c}9 \\
(16.98)\end{array}$ & $5(-9.43)$ & $\begin{array}{c}36 \\
(67.92)\end{array}$ & $5(9.43)$ & $\begin{array}{c}4(- \\
7.55)\end{array}$ & $\begin{array}{c}44 \\
(83.02)\end{array}$ & $6(11.32)$ & $\begin{array}{c}8 \\
(15.09)\end{array}$ & $\begin{array}{c}39 \\
(73.58)\end{array}$ & $2(3.77)$ & $4(7.55)$ & $\begin{array}{c}47 \\
(88.68)\end{array}$ & $3(5.66)$ & $5(9.43)$ & $\begin{array}{c}45 \\
(84.91)\end{array}$ \\
\hline $\begin{array}{l}\text { Resident, } \\
\text { number } \\
(\%)\end{array}$ & $\begin{array}{c}8 \\
(19.51)\end{array}$ & $\begin{array}{c}10(- \\
24.39)\end{array}$ & $\begin{array}{c}15 \\
(36.59)\end{array}$ & $\begin{array}{c}6 \\
(14.63)\end{array}$ & $\begin{array}{c}14(- \\
34.15)\end{array}$ & $\begin{array}{c}21 \\
(51.22)\end{array}$ & $4(9.76)$ & $\begin{array}{c}11 \\
(26.83)\end{array}$ & $\begin{array}{c}26 \\
(63.41)\end{array}$ & $0(0)$ & $1(2.44)$ & $\begin{array}{c}40 \\
(97.56)\end{array}$ & $2(4.88)$ & $4(9.76)$ & $\begin{array}{c}35 \\
(85.37)\end{array}$ \\
\hline $\mathrm{P}$ & 0.7 & 0.05 & 0.002 & 0.53 & 0.001 & 0.001 & 0.81 & 0.16 & 0.29 & 0.5 & 0.38 & 0.1 & $>0.999$ & $>0.999$ & 0.95 \\
\hline $\begin{array}{c}\text { Surgical } \\
\text { Residents }\end{array}$ & $6(35.3)$ & $4(23.5)$ & 7 (41.2) & $4(23.5)$ & $\begin{array}{c}8 \\
(47.1)\end{array}$ & $\begin{array}{c}5 \\
(29.4)\end{array}$ & 2 (11.7) & 5 (29.4) & $\begin{array}{c}10 \\
(58.8)\end{array}$ & $0(0)$ & $1(5.9)$ & $\begin{array}{c}16 \\
(94.1)\end{array}$ & 2 (11.7) & 3 (17.6) & $\begin{array}{c}12 \\
(70.6)\end{array}$ \\
\hline $\begin{array}{l}\text { Anesthesia } \\
\text { Residents }\end{array}$ & $9(37.5)$ & 7 (29.2) & 8 (33.3) & 4 (16.7) & $\begin{array}{c}5 \\
(20.1)\end{array}$ & $\begin{array}{c}15 \\
(62.5)\end{array}$ & $3(12.5)$ & 5 (20.8) & $\begin{array}{c}16 \\
(66.7)\end{array}$ & $2(2.1)$ & $0(0)$ & $\begin{array}{c}24 \\
(100)\end{array}$ & $0(0)$ & $2(8.3)$ & $\begin{array}{c}22 \\
(91.6)\end{array}$ \\
\hline$P$ value $^{2}$ & 0.89 & 0.69 & 0.61 & 0.58 & 0.08 & 0.004 & 0.58 & 0.53 & 0.61 & NA & 0.23 & 0.23 & 0.08 & 0.37 & 0.5 \\
\hline
\end{tabular}

$\mathrm{BO} / \mathrm{DP}$ - burning and/or depression, $\mathrm{P}$ value addressed difference in proportions between All Attendings and All Residents.

\section{Discussion}

Even though operating room-related specialists, surgeons and anesthesiologists, are not the most vulnerable physicians compared to other specialties, the consequences of BO/DP symptoms can lead to catastrophic mistakes directly jeopardizing patients' lives. Is there anything can be done to fix the problem? In our opinion, there are two different ways to approach this situation:

a) Change the priority in healthcare management from cost-control and profitability to quality-of-care and patient/ staff satisfaction.

b) Improve the management of the operating room through better inter-departmental education and teamwork.

Since the first scenario looks highly unrealistic in the current political and economic situation, the second approach is likely to be more viable. Physicians in general, and surgeons and anesthesiologists by their nature and training represent a category of autonomous and independent "high achievers." The main goal of their work is to provide uncompromised quality of care to patients. However, the dissonance between the time and effort applied in order to achieve this goal, low control over the outcome [13] combined with continuous pressure for production may lead to diametric responses from physicians and administrators. Administrators respond by applying more paperwork, rules and regulations [14] most of which are viewed by clinicians as unnecessary bureaucratic obstacles, taking valuable time from delivering high quality personalized care.

Physicians, in some cases, respond to this type of "institutionalized abuse" in a form of disruptive behavior ranging from passive disrespect to straight aggression [15,16]. Even though most physicians are able to cope and accommodate this situation, even a small number of uncooperative individuals can create tremendous tension at the workplace, decreasing quality of care and overall staff and patient satisfaction [17]. The highly politicized US healthcare system is designed to prevent physicians (in particular) from taking control of their own working environment. Since the establishment of a centralized 
and essentially unionized structure is not an option, cooperation and teamwork at the local level can help significantly diminish the physical and psychological load on existing and future generations of practitioners. How do we reach this state of equanimity? In our opinion, the path is through appropriate education in management.

Multiple attempts to improve the quality of OR management and teamwork have been made, however, without specifically focusing on the issue of BO/DP. Most of these activities are slightly modified protocols acquired from the aviation industry [18] and are based on the vague assumption that the relationship between members of the OR team somehow resemble the same as in airplane cockpit. Obviously, the effect of these borrowed protocols on physician wellbeing has never been evaluated. In our opinion, now is the perfect time for our industry to take medicine into our own hands and become more creative in ways of developing new industry-specific managerial methodologies and protocols [19].

\section{Conclusion}

Even though the presented data is preliminary and this research is still a work in progress, it clearly shows the importance of the issue itself as well as the value of effective OR management, teamwork and communication as a useful tool to minimize the effect on burnout and depression on physician quality of life, potentially improving physician-to-physician, physician-topatient relationship and quality of patients care.

\section{References}

1. Colin P West, Liselotte N Dyrbye, Patricia J Erwin, Shanafelt TD (2016) Interventions to prevent and reduce physician burnout: a systematic review and meta-analysis. The Lancet 388(100057): 2272-2281.

2. Tait D Shanafelt, Lotte N Dyrbye, Christine Sinsky, Hasan O, Satele D, et al. (2016) Relationship Between Clerical Burden and Characteristics of the Electronic Environment with Physician Burnout and Professional Satisfaction. Mayo Clinic Proceedings 91(7): 836-848.

3. Raymond T Lee, Bosu Seo, Steven Hladkyj, Lovell BL, Schwartzmann L, et al. (2013) Correlates of physician burnout across regions and specialties: a meta-analysis. Human Resources for Health 11: 48.

This work is licensed under Creative Commons Attribution 4.0 License

DOI:_10.19080/JAICM.2019.08.555748
4. Bianca Banova (2013) The Impact of Technology on Healthcare. American Institute of medical sciences and education.

5. Rod Moser (2013) The Depersonalization of Medicine. WebMD.

6. Shanafelt T, Boone S, Tan L, Dyrbye LN, Sotile W, et al. (2012) Burnout and satisfaction with work-life balance among US physicians relative to the general US population. Arch Intern Med 172(18): 1377-1385.

7. (2018) Medscape National Physician Burnout \& Depression Report p. 3.

8. (2016) Medscape Anesthesiology Lifestyle Report: Bias and Burnout p. 2.

9. (2016) Medscape Anesthesiology Lifestyle Report: Bias and Burnout p. 5.

10. (2018) Medscape Anesthesiologist Lifestyle Report: Personal Happiness vs Work Burnout p. 7.

11. Delli Fraine, Jami L, Langabeer James R, Nembhard Ingrid M (2010) Assessing the Evidence of Six Sigma and Lean in the Health Care Industry. Quality Management in Health Care 19(3): 211-225.

12. Chernov M, Pullockaran J, Vick A, Leyvi G, Delphin E (2016) Integrated Practice Improvement Solutions-Practical Steps to Operating Room Management. J Invest Surg 29(5): 316-321.

13. Mikhail Chernov, Angela Vick, Sujatha Ramachandran, Ellise Delphin (2017) Introducing "4 Steps-to-Team" - An Innovative Educational Concept for Teambuilding in The Operating Room. J Anesth Perioper Med 4(6): 293-296.

14. Drummond Dike (2018) Physician burnout: Why its not a fair fight?

15. Jesse, M Ehrenfeld, Jonathan P Wanderer (2018) Technology as friend or foe? Do electronic health records increase burnout? Current Opinion in Anesthesiology 31(3): 357-360.

16. Benzer DG, Miller MM (1995) The disruptive-abusive physician: a new look at an old problem. Wis Med J 94(8): 455-460.

17. David O Weber (2004) For Safety's Sake Disruptive behavior must be tamed. Managing disruptive physician behavior. American College of Physician Executives 30(5): 16-17.

18. Horty J, Barker M (1987) Disruptive physicians in the OR direct threat to patient care 3(8): 6-7.

19. Kim, Linda Y (2014) The Effects of Simulation-based Team STEPPS Interprofessional Communication and Teamwork Training on Patient and Provider Outcomes. University of California, Los Angeles p. 11-12.

Your next submission with Juniper Publishers
will reach you the below assets
- Quality Editorial service
- Swift Peer Review
- Reprints availability
- E-prints Service
- Manuscript Podcast for convenient understanding
- Global attainment for your research
- Manuscript accessibility in different formats
( Pdf, E-pub, Full Text, Audio)
- Unceasing customer service
Track the below URL for one-step submission
https://juniperpublishers.com/online-submission.php

